\title{
THE RELATIONSHIP OF VACUUM CHILDBIRTH WITH THE INCIDENCE OF ASPHYXIA NEONATORUM
}

\author{
Fatsiwi Nunik Andari ${ }^{1}$, Mika Ilma ${ }^{2}$, Nurhayati ${ }^{3}$, Panzilion ${ }^{4}$ \\ ${ }^{1,2,3,4}$ Program Studi Profesi Ners UM Bengkulu
}

Email: fatsiwiandari@umb.ac.id

\begin{abstract}
Asphyxia neonatorum is a condition that needs attention because it is related to the quality of life so that at every delivery it is hoped that there will be no disabilities that can affect life in the future. The purpose of this study was to determine the relationship between the relationship of vacuum childbirth with the incidence of asphyxia neonatorum in RSUD Dr. M. Yunus Bengkulu. This research was a quantitative study with a cross sectional design. The total sample was 115 patients that who experienced asphyxia at birth by vacuum extraction. The results showed there was a significant correlation between vacuum childbirth with the incidence of asphyxia neonatorum in RSUD Dr. M. Yunus Bengkulu with $\mathrm{p}$ value $<0.05$ and the degree of relationship between the two variables in the medium category $(\mathrm{C}$ $=0.435$ ). The suggest especially for nursing and midwifery are advised to provide health information for pregnant women to prevent the incidence of asphyxia neonatorum during their pregnant.
\end{abstract}

Keywords: asphyxia neonatorum, childbirth, vacuum extraction

\section{PENDAHULUAN}

Angka Kematian Bayi (AKB) adalah jumlah kematian bayi dalam usia 28 hari pertama kehidupan per 1.000 kelahiran hidup. Data World Health Organization (WHO) tahun 2015 menunjukkan bahwa angka kematian bayi khususnya neonatus sebesar 10.000.000 jiwa per tahun. Angka kematian bayi di Indonesia menempati urutan tertinggi dibanding Negara ASEAN lainnya yaitu 27 per 1000 kelahiran hidup, sementara di Singapura 3 per 1000 kelahiran hidup, Malaysia 5,5 per 1000 kelahiran hidup, Thailand 17 per 1000 kelahiran hidup, dan Vietnam 18 per 1000 kelahiran hidup.

Jurnal Vokasi Keperawatan (JVK) Volume 4 No 1 Bulan Juni Tahun 2021 Program Study of Nursing Universitas Bengkulu http ://ejournal.unib.ac.id/index.php/JurnalVokasiKeperawatan 
Menurut Survei Demografi Kesehatan Indonesia (SDKI) tahun 2015 hasil Survei Penduduk Antar Sensus (SUPAS) 2015, angka kematian bayi sebesar 22,23 per 1.000 kelahiran hidup. Angka kematian bayi di Provinsi Bengkulu tercatat sebanyak 355 kematian (Dinas Kesehatan Provinsi Bengkulu, 2015).

Salah satu penyebab kematian bayi adalah asfiksia neonatorum. Asfiksia neonatorum adalah suatu keadaan bayi baru lahir yang gagal bernafas secara spontan dan teratur segera setelah lahir, sehingga terjadi penurunan oksigen $\left(\mathrm{O}_{2}\right)$ dan peningkatan karbondioksida $\left(\mathrm{CO}_{2}\right)$ yang menimbulkan dampak buruk dalam kehidupan lebih lanjut (Jumiarni, Mulyati, \& Nurlina, 2016). Asfiksia merupakan kondisi kegawatdaruratan pada bayi berupa kegagalan bernafas secara spontan segera setelah lahir dan sangat beresiko untuk terjadinya kematian (Ligawati, 2018).

Asfiksia menempati penyebab kematian bayi setiap tahunnya kira-kira 3\% (3,6 juta). Angka kematian bayi di dunia akibat asfiksia adalah 4,6 per 1.000 kelahiran hidup. Dari 120 juta bayi baru lahir dengan asfiksia, hampir 1 juta dari bayi tersebut meninggal dunia (WHO, 2012). Di Indonesia, angka kematian bayi akibat asfiksia sebesar 27\% (Kemenkes RI, 2014). Di Provinsi Bengkulu pada tahun 2015, dari 24.027 kelahiran hidup terdapat 266 bayi lahir mati dan jumlah kematian bayi sebesar 358 (Dinkes Provinsi Bengkulu, 2015). Asfiksia dapat dipengaruhi dari beberapa faktor, baik dari faktor ibu, janin/ bayi, plasenta, mapn faktor persalinan. Faktor dari ibu yang dapat menyebabkan asfiksia yaitu usia ibu kurang dari 20 tahun atau lebih dari 35 tahun, paritas, preeklamsia. Faktor dari janin maupun bayi yaitu berat badan lahir rendah (BBLR), intrauterine growth retardation (IUGR), prematuritas, tali pusat menumbung, lilitan tali pusat. Faktor plasenta yaitu plasenta tipis, kecil, solusio plasenta. Faktor persalinan yaitu partus lama, partus dengan tindakan dan persalinan dengan sectio caesaria (Saifuddin, 2011; Sari dan Rimandini, 2014). 
Persalinan dengan tindakan seperti ekstraksi vakum merupakan salah satu faktor risiko terjadinya asfiksia. Persalinan dengan tindakan ekstraksi vakum menyebabkan terjadinya asfiksia neonatorum sebesar $62,5 \%$ lebih besar daripada persalinan normal. Ibu primipara dengan persalinan ekstraksi vakum memiliki risiko terjadinya asfiksia neonatorum 3,98 kali (Andromeda, Santoso, dan Hernayanti, 2012).

Berdasarkan survey awal yang dilakukan peneliti di RSUD Dr M. Yunus Bengkulu, pada tahun 2014 jumlah ibu yang bersalin tercatat sebanyak 1.101 orang, bayi yang mengalami asfiksia dalam persalinan tersebut sebanyak 147 orang dan ibu yang menjalani persalinan dengan tindakan ekstraksi vakum sebanyak 49 orang. Pada tahun 2015 jumlah ibu yang bersalin sebanyak 1.330. Persalinan pervaginam spontan sebanyak 115 orang dengan bayi yang mengalami asfiksia sebanyak 50 orang. Dari jumlah tersebut, 45 orang bayi dilahirkan dengan tindakan ekstraksi vakum dan 5 orang tidak dilakukan tindakan ekstraksi vakum namun mengalami asfiksia (Profil RSUD DR. M. Yunus Bengkulu, 2015). Berdasarkan uraian ini maka peneliti tertarik untuk meneliti tentang "hubungan persalinan ekstraksi vakum dengan kejadian asfiksia neonatorum di Ruang Kebidanan Rumah Sakit Dr M. Yunus Bengkulu”.

\section{METODE}

Peneitian ini adalah penelitian kuantitatif dengan rancangan penelitian deskriptif analitik dengan menggunakan desain cross sectional. Populasi dalam penelitin ini adalah seluruh ibu yang bersalin pervaginam spontan vakum yang tercatat dalam pendokumentasian status pasien atau data rekam medis Ruang Kebidanan RSUD Dr. M. Yunus Bengkulu yaitu sebanyak 115 orang.

Pengambilan sampel pada penelitin ini menggunakan tehnik total sampling yaitu pengambilan sampel secara keseluruhan dari populasi. Pengumpulan data dilakukan dengan menggunakan lembar check list. Data yang telah terkumpul dari 
semua responden kemudian dianalisis secara statistiik baik dengan analisis univariat maupun bivariat dengan menggunakan uji Chi-Square $\left(\mathrm{X}^{2}\right)$ (Nursalam, 2013).

\section{HASIL}

\section{Analisis Univariat}

Tabel 1. Distribusi Frekuensi Persalinan Pervaginam Spontan Di RSUD Dr. M. Yunus Bengkulu

\begin{tabular}{|c|c|c|c|c|c|}
\hline \multirow{2}{*}{\multicolumn{2}{|c|}{ Variabel }} & \multicolumn{2}{|c|}{ Pervaginam Spontan } & \multicolumn{2}{|c|}{ Total } \\
\hline & & $\mathbf{N}$ & $\%$ & $\mathbf{N}$ & $\%$ \\
\hline \multirow[t]{2}{*}{ Persalinan } & Dilakukan vakum & 45 & 39.1 & & \\
\hline & $\begin{array}{l}\text { Tidak dilakukan } \\
\text { vakum }\end{array}$ & 70 & 60.9 & 115 & 100 \\
\hline
\end{tabular}

Berdasarkan Tabel 1 di atas dapat diketahui bahwa proporsi persalinan pervaginam spontan tanpa dilakukan tindakan ekstraksi vakum lebih besar $(60.9 \%)$ dibandingkan persalinan dengan tindakan ekstraksi vakum (39.1\%).

Tabel 2. Distribusi Frekuensi Kejadian Afiksia Neonatorum Di RSUD Dr. M. Yunus Bengkulu

\begin{tabular}{|c|c|c|c|c|c|}
\hline \multirow{2}{*}{\multicolumn{2}{|c|}{ Variabel }} & \multicolumn{2}{|c|}{ Frekuensi } & \multicolumn{2}{|c|}{ Total } \\
\hline & & $\mathbf{N}$ & $\%$ & $\mathbf{N}$ & $\%$ \\
\hline \multirow{2}{*}{ Kejadian Asfiksia } & Asfiksia & 50 & 43.5 & \multirow{2}{*}{115} & \multirow{2}{*}{100} \\
\hline & Tidak Asfiksia & 65 & 66.5 & & \\
\hline
\end{tabular}

Berdasarkan Tabel 2. di atas dapat diketahui bahwa proporsi bayi yang mengalami asfiksia neonatorum sedikit lebih kecil (43.5\%) dibandingkan bayi yang tidak mengalami asfiksia $(66.5 \%)$.

\section{Analisa Bivariat}

Tabel 3. Tabulasi Silang Persalinan Tindakan Ekstraksi Vakum dengan Kejadian Asfiksia Neonatorum Di RSUD Dr. M. Yunus Bengkulu

\begin{tabular}{cccccccc}
\hline \multirow{2}{*}{$\begin{array}{c}\text { Tindakan } \\
\text { vakum }\end{array}$} & \multicolumn{2}{c}{ Kejadian Asfiksia } & Total & $\mathbf{X}^{\mathbf{2}}$ & $\mathbf{C}$ & $\mathbf{O R}$ & $\boldsymbol{p}$-value \\
\cline { 2 - 4 } & Ya & Tidak & & & & & \\
Dilakukan & 33 & 12 & 45 & & & \\
Tidak dilakukan & 17 & 53 & 70 & & 0.435 & 8.5 & 0.000 \\
Total & 50 & 65 & 115 & & & & \\
\hline \hline
\end{tabular}

Jurnal Vokasi Keperawatan (JVK) Volume 4 No 1 Bulan Juni Tahun 2021 Program Study of Nursing Universitas Bengkulu http ://ejournal.unib.ac.id/index.php/JurnalVokasiKeperawatan 
Berdasarkan Tabel 3. di atas dapat diketahui bahwa dari 45 ibu yang bersalin dengan tindakan ekstraksi vakum terdapat 33 bayi yang mengalami asfiksia dan 12 bayi tidak mengalami asfiksia. Sementara itu dari 70 ibu yang bersalin spontan tanpa tindakan vakum, terdapat 17 bayi yang mengalami asfiksia dan 53 bayi tidak mengalami asfiksia.

Hasil penelitian juga menunjukkan bahwa nilai chi-square $\left(\mathrm{X}^{2}\right)$ sebesar 24,855 dan $p$-value 0,000 . Nilai $\mathrm{p}<0,05$ maka dapat disimpulkan bahwa ada hubungan yang signifikan antara persalinan tindakan ekstraksi vakum dengan kejadian asfiksia neonatorum di Ruang Kebidanan RSUD Dr. M. Yunus Bengkulu.

Derajat hubungan antara persalinan ekstraksi vakum dengan kejadian asfiksia diukur dari nilai Koefisien Kontingensi (C) dengan nilai pembanding C_max= 0,707. Nilai $\mathrm{C}$ pada penelitian ini adalah 0,435 yang artinya cukup dekat dengan nilai C_max, maka dapat disimpulkan bahwa variabel persalinan ekstraksi vakum dengan variabel asfiksia neonatorum memiliki derajat hubungan dengan kategori sedang, yang artinya bahwa kejadian asfiksia tidak hanya disebabkan oleh tindakan ekstraksi vakum namun disebabkan juga oleh faktor lainnya yang tidak diteliti dalam penelitian ini seperti gawat janin, kala II yang lama, paritas, usia ibu dan jenis persalinan yang terjadi. Hasil penelitian juga menunjukkan bahwa persalinan dengan tindakan ekstraksi vakum memiliki resiko terjadinya asfiksia 8.5 kali lipat bila dibandingkan dengan persalinan normal.

\section{PEMBAHASAN}

Berdasarkan hasil penelitian diketahui bahwa mayoritas responden (60.9\%) melakukan persalinan pervaginam spontan tanpa dilakukan tindakan ekstraksi vakum. Hal ini dikarenakan kondisi ibu bersalin dalam keadaan yang baik, tidak mengalami preeklamsia, asma, riwayat penyakit jantung, maupun riwayat penyakit lainnya yang menimbulkan resiko dalam persalinan. Kemampuan ibu 
untuk mengejan baik, kondisi janin baik, tidak mengalami gawat janin, serta kondisi plasenta juga baik.

Hasil penelitian ini didukung oleh hasil penelitian Pratama, Hanum, dan Budi (2018) bahwa sebagian besar responden (73\%) melakukan persalinan pervaginam tanpa tindakan ekstraksi vakum. Melahirkan secara normal merupakan keinginan sebagian besar ibu hamil, meskipun prosesnya lama dan menyakitkan. Sebagian wanita merasa telah benar-benar menjadi seorang ibu di saat mereka dapat melahirkan bayinya dengan proses normal, dimana mereka benar-benar merasakan bagaimana rasa sakit saat berjuang untuk melahirkan buah hatinya. Selain itu, proses persalinan secara normal lebih direkomendasikan, hal ini dikarenakan banyak manfaat yang didapat dari proses persalinan normal diantaranya kondisi bayi lebih baik karena terhindar dari berbagai macam bahan kimia, bayi yang dilahirkan secara normal lebih tertarik untuk melakukan proses inisiasi menyusui dini (IMD), dan nyeri pasca bersalin tidak lagi dirasakan oleh ibu.

Persalinan spontan pervaginam yang tidak berjalan lancar karena adanya penyulit baik dari ibu ataupun janin, maka akan dibantu dengan tindakan, salah satunya dengan ekstraksi vakum untuk menyelamatkan nyawa ibu dan bayi dalam kandungannya (Mose \& Alamsyah, 2010). Ekstraksi vakum adalah suatu persalinan buatan dengan prinsip antara kepala janin dan alat penarik mengikuti gerakan alat vakum ekstraktor (Sarwono, 2011). Namun, tidak semua persalinan spontan pervaginam yang tidak lancer dibantu dengan tindakan ekstraksi vakum

Ekstraksi vakum dilakukan apabila indikasi persalinan dan syarat persalinan terpenuhi. Menurut teori indikasi persalinan dengan ekstraksi vakum yaitu ibu yang mengalami kelelahan tapi masih memiliki kekuatan untuk mengejan, partus macet pada kala II (kala II yang lama), terjadi gawat janin, toksemia gravidarum, dan ancaman terjadinya ruptur uteri. Sementara syarat yang harus dipenuhi adalah janin aterm, tidak ada disproporsi, pembukaan serviks sudah lengkap, kepala janin 
sudah enganged atau turunnya bayi ke panggul, dan selaput ketuban sudah pecah, atau bila belum maka akan dipecahkan (Angsar, 2010).

Hasil penelitian menunjukkan bahwa bayi yang dilahirkan dengan tindakan ekstraksi vakum sebagian besar yaitu 33 bayi (73.3\%) mengalami asfiksia neonatorum. Hasil yang berbeda terdapat pada hasil penelitian Mar'tussaliha dan Rismayanti (2017) yang menunjukkan bahwa kejadian asfiksia neonatorum lebih banyak terjadi pada partus normal yaitu sebanyak 49 bayi (71\%) dibandingkan dengan partus lama yaitu sebanyak 20 bayi (29\%), dan liltan tali pusat 30 bayi (43\%). Asfiksia dapat terjadi karena beberapa faktor, mulai dari faktor ibu seperti usia ibu yang kurang dari 20 tahun atau lebih dari 35 tahun, banyaknya jumlah persalinan yang telah dialami (paritas), hipertensi dalam kehamilan (preeklamsia). Faktor dari janin maupun bayi seperti berat badan lahir rendah (BBLR), intrauterine growth retardation (IUGR), prematuritas, tali pusat menumbung, lilitan tali pusat. Faktor plasenta seperti plasenta tipis, kecil, solusio plasenta dan faktor persalinan seperti partus lama, partus dengan tindakan dan persalinan dengan sectio caesaria (Jumiarni, Mulyati, \& Nurlina., 2016).

Pada penelitian ini asfiksia terjadi karena keadaan ibu yang tidak baik, adanya gangguan his, persalinan yang memanjang atau lama, perdarahan, ibu dengan persalinan prematur, dan persalinan lewat waktu atau post term. Hasil penelitian ini juga menunjukkan ada hubungan yang signifikan antara persalinan tindakan ekstraksi vakum dengan kejadian asfiksia neonatorum di Ruang Kebidanan RSUD Dr. M. Yunus Bengkulu dengan p-value 0,000 dan derajat hubungan pada kategori sedang $(\mathrm{C}=0,435)$ yang berarti bahwa kejadian asfiksia tidak hanya disebabkan oleh tindakan ekstraksi vakum namun disebabkan juga oleh faktor lain. Hasil penelitian juga menunjukkan bahwa persalinan dengan tindakan ekstraksi vakum memiliki resiko terjadinya asfiksia 8.5 kali lipat bila dibandingkan dengan persalinan normal. 
Hasil penelitian ini sejalan dengan hasil penelitian Andromeda, Santoso, dan Hernayanti (2012) bahwa persalinan ekstraksi vakum menyebabkan terjadinya asfiksia neonatorum di RSUD Panembahan Senopati Bantul sebesar 62.5\%. Hasil penelitian ini juga memperkuat hasil penelitian Widiyanti dan Dewi (2017) bahwa ada hubungan yang signifikan antara persalinan ekstraksi vakum dengan kejadian asfiksia neonatal atau asfiksia neonatorum. Persalinan ekstraksi vakum menyebabkan bayi mengalami asfiksia dikarenakan oleh tekanan negatif yang diciptakan alat vakum tersebut. Tekanan negatif tersebut menimbulkan ruang hampa pada kepala, menciptakan kaput serta tarikan dan tekanan negatif pada kepala bayi. Penarikan definitif dilakukan pada saat ada his. Sedangkan saat his, pasokan oksigen dari tali pusat ke bayi berkurang. Saat his berlangsung dan penolong melakukan tarikan, maka dapat terjadi perdarahan otak. Selain itu juga pasokan oksigen ke otak bayi berkurang sehingga bayi mengalami asfiksia (Sarwono, 2011).

Komplikasi lain dari vakum ekstraksi adalah perdarahan intrakranial. Perdarahan ini disebabkan oleh tekanan yang terlalu tinggi dan lama pada kepala bayi. Perdarahan intrakranial ini pada akhirnya akan menyebabkan kondisi yang lebih berbahaya yaitu perdarahan dalam otak. Pada perdarahan intrakranial, aliran darah pada otak janin menjadi terhambat dan pasokan $\mathrm{O} 2$ ke otak janin menjadi berkurang. Hal ini menyebabkan gangguan pernafasan pada bayi atau apnea yang pada akhirnya akan menyebabkan asfiksia pada saat bayi lahir (Manuaba, 2012).

Asfiksia neonatorum. erat kaitannya dengan hipoksia janin dalam uterus. Hipoksia ini berhubungan dengan faktor-faktor yang timbul dalam kehamilan, persalinan atau segera lahir Oleh karena itu menjaga kesehatan dengan memeriksakan kondisi bayi selama masa kehamilan sangat penting dilakukan (Nugroho, 2015). Bayi dengan kondisi asfiksia neonatorum yang mampu bertahan hidup jumlahnya cukup banyak, namun dapat mengalami kerusakan di bagian otak. Hal ini disebabkan karena resusitasi yang tidak adekuat atau salah dalam pelaksanaan prosedurnya. Resusitasi yang dilaksanakan secara adekuat dapat mencegah 
kematian dan kecacatan pada bayi karena hipoksia. Intervensi post natal terhadap peningkatan keterampilan resusitasi bayi baru lahir dapat menurunkan kematian neonatal mencapai sekitar 6-42\% (The Lancet Neonatal Survival, 2005).

\section{SIMPULAN DAN SARAN}

\section{SIMPULAN}

a. Proporsi persalinan pervaginam spontan tanpa dilakukan tindakan ekstraksi vakum lebih besar (60.9\%) dibandingkan persalinan dengan tindakan ekstraksi vakum $(39.1 \%)$.

b. Proporsi bayi yang mengalami asfiksia neonatorum saat lahir sedikit lebih kecil (43.5\%) dibandingkan bayi yang tidak mengalami asfiksia (66.5\%).

c. Ada hubungan yang signifikan antara persalinan tindakan ekstraksi vakum dengan kejadian asfiksia neonatorum di RSUD Dr. M. Yunus Bengkulu dengan $p$-value $=0.000$ dan derajat hubungan kedua variabel dalam kategori sedang $(\mathrm{C}=0.435)$.

\section{SARAN}

Saran yang diharapkan khususnya kepada tenaga keperawatan dan kebidanan disarankan untuk dapat memberikan infomasi kesehatan kepada ibu hamil di masa kehamilannya untuk mencegah terjadinya asfiksia saat persalinan baik persalinan spontan secara normal maupun persalinan dengan tindakan ekstraksi vakum.

\section{DAFTAR RUJUKAN}

Andromeda, Santoso, dan Hernayanti. (2012). Faktor Resiko Persalinan Ekstraksi Vakum pada Primipara terhadap Asfiksia Neonatorum Di RSUD Panembahan Senopati Bantul. http://www.ejournal.poltekkesjogja.ac.id/index.php/kia/article/download/174/105

Angsar, D. M. (2010). Ilmu Bedah Kebidanan: Ekstraksi Vakum dan Forsep. Jakarta: PT Bina Pustaka.

Dinas Kesehatan Provinsi Bengkulu. (2015). Profil Kesehatan Provinsi Bengkulu. Jumiarni, Mulyati, \& Nurlina, 2016). Asuhan Keperawatan Perinatal. Jakarta: EGC. 
Kemenkes RI. (2014). Profil Kesehatan Indonesia. Jakarta: Pusdatin Kementerian Kesehatan Republik Indonesia.

Manuaba, I. B. G. (2012). Pengantar Kuliah Obstetri dan Ginekologi. Jakarta: Penerbit Buku Kedokteran EGC.

Mar'tussaliha dan Rismayanti. (2017). Gambaran kejadian Asfiksia Bayi Baru Lahir Di Rumah Sakit Umum Daerah Pangkep Periode Januari sampai April 2017.

http://jurnal.stikesnh.ac.id/index.php/jikd/article/view/155

Mose, C. J \& Alamsyah, M. (2010). Ilmu Kebidanan Sarwono Prawirohardjo: Persalinan Lama. Jakarta: PT Bina Pustaka.

Nugroho, P. M. C. (2015). Tingkat Keparahan Asfiksia Neonatorum pada Bayi Berat Lahir Rendah. Jurnal Kedokteran Muhammadiyah. https://jurnal.unimus.ac.id/index.php/kedokteran/article/view/1753

Nursalam. (2013). Metodologi Penelitian Ilmu Keperawatan. Jakarta: Salemba Medika.

Pratama, Hanum, dan Budi. (2018). Angka Kejadian Asfiksia Neonatorum pada Bayi dengan Berat Badan Lahir Rendah Di RSUD Goeteng Taroenadibrata Purbalingga. http://jurnalnasional.ump.ac.id/index.php/HMJ/article/view/3098

Saifuddin, A. B. (2011). Buku Panduan Praktis Pelayanan Kesehatan Maternal Neonatal. Jakarta: PT. Bina Sarwono Prawirohardjo.

Sari, E. P dan Rimandini, K. D. (2014). Asuhan Kebidanan pada Persalinan Cetakan1. Jakarta: Trans Info Medika

Sarwono. (2011). Ilmu Kebidanan. Jakarta: TBPSP.

Survei Demografi Kesehatan Indonesia. (2015). Survei Penduduk Antar Sensus (SUPAS) 2015. Jakarta.

The Lancet. (2005). Neonatal Survival. Elsevier.

Widiyanti dan Dewi. (2017). Kejadan Asfksa Neonatorum pada Tindakan Ekstraksi Vakum pada Bayi Baru Lahir. http://journal.umuslim.ac.id/index.php/jka/article/view/316 